\title{
E-SAFETY AND DIGITAL SKILLS AS PART OF SCHOOL CURRICULUM
}

\section{Lidija Kralj}

STRUČNI RAD / DOI: 10.20901/ms.7.13.4 / PRIMLJENO: 12.01.2016.

\begin{abstract}
In order to respond to the needs for empowering students, teachers and parents in the area of e-safety, electronic violence prevention and digital skills, five primary schools in Croatia carried out the project called "Children's safety on the Internet". In this paper we discuss the content and evaluation of school curriculum "Children's safety on the Internet" developed in that project and the findings emerged from the curriculum piloting in early grades, $1-4$, with students aged 7 to 10, their parents and teachers. The results show that the curriculum and learning resources met students' expectations and that the team of authors successfully implemented modern teaching strategies in the curriculum and resources (textbooks, guides, interactive multimedia, e-books) creation although some of the results showed that certain lessons need clarification to fulfil the expected learning outcome. The results of the piloting were immediately used for improving the quality of the curriculum and after that all learning and teaching resources were published online for free. Learning resources have found their place in the proposal for the new national curriculum for the cross-curricular subject called Use of ICT as well as in the curriculum for the school subject of Informatics in all primary and secondary schools in Croatia.
\end{abstract}

KEY WORDS

E-SAFETY, ELECTRONIC VIOLENCE PREVENTION, SCHOOL CURRICULUM, DIGITAL SKILLS

Author note.

Lidija Kralj :: Algebra University College, Zagreb, Croatia :: lidija.kralj@ucitelji.hr 


\section{INTRODUCTION}

The need to prepare young people for everyday interaction with information and communication technology (ICT) has been recognised by the European Parliament and the Council of the European Union in their Recommendation on key competences for lifelong learning. One of the key competences listed in that recommendation is digital competence each person needs to have in order to adapt to the rapidly changing world (European Parliament and the Council, 2006). Digital competence involves persons' ability to confidently and critically use information and communication technology for work, private and social life and communication. The key elements of digital competence are basic ICT skills and abilities: to use a computer to search, assess, save, create, present and exchange information as well as to develop collaboration networks via the Internet (Ferrari, 2013).

In this digital age children are focused on computers and mobile devices from early childhood. It is of utmost importance to teach them how to use these devices properly and appropriately (Mark and Ratliffe, 2011).

At the moment, children at Croatian primary schools have an opportunity to acquire key digital skills if they choose the elective subject of Informatics in grades 5 to 8 , or as early as grades 1 to 4 if they have been involved in an extracurricular activity (MZOS, 2006: 310-320). However, the topic of e-safety is not part of any subject curriculum for primary schools. Not even a minimum knowledge on responsible and safe use of the Internet is obligatory for students according to the Croatian curriculum. Raising awareness and safer Internet activities are promoted in Croatia by different NGOs. In such activities students take part thanks to their teachers' enthusiasm but without any systematic support (Kanižaj et al., 2014).

Without any strategy and with NGOs as the cornerstone of media education in Croatia, children and youth are facing many media challenges, primarily cyberbullying, but also sexting and grooming through social networks. (Kanižaj et al., 2014)

The EU Kids Online research "Risks and safety on the internet" encompassing 25 countries in 2011 (Livingstone et al., 2011) showed that the average age of first internet use is seven, that $93 \%$ of children aged $9-16$ use the internet daily or several times a week and that $55 \%$ of children have public profiles with personal information published on social networks. $13 \%$ of European children say that they have been harassed or upset by something on the Internet. The comparison made by EU Kids Online in 2014 (Livingstone et al., 2014) showed increase in internet usage and online risk; cyberbullying and harassment to $18 \%$, use of social network sites to $68 \%$. None of these research includes data for Croatia.

According to the UNICEF's survey in Croatia (Pregrad et al., 2011), 85\% of children have Internet access at home. Their favourite activities on the Internet are seeking entertainment, communicating with friends, and using social networking sites; while using the Internet for research and learning is less frequent. The same survey showed that $34 \%$ of children experienced some form of electronic violence and that the usual 
teachers' reaction when faced with such cases is asking for advice from an expert, which shows that teachers do not feel to be competent to deal with e-safety issues. Research that Hrabri telefon ('Brave Phone') and Poliklinika za zaštitu djece grada Zagreba (Child Protection Centre of Zagreb) made in 2013, showed that $99 \%$ of children have Internet access at home or at school, $93 \%$ have a profile on a social network site and $21 \%$ received nasty messages or comments several times on Facebook (Buljan Flander, 2013).

The forementioned research findings from the EU Kids Online and UNICEF suggest that children's digital skills training needs to be continually emphasised and updated in terms of training methods, safety features and content to ensure that all children reach a minimum basic standard knowledge, as well as to prevent children from being digitally isolated and unskilled (Livingstone et al., 2011; Pregrad et al., 2011; Kralj, 2014).

Some of the threats Igor Kanižaj et al. (2014) emphasised in mapping Media and Information Literacy Policies in Croatia are: poor and not consistent teacher education, poor textbooks and training materials regarding media education, including e-safety. Media education is part of initial training only for teachers of Croatian; continuous training for teachers rely mostly on their personal interest, so usually they do not have an opportunity to attend courses about media and information literacy, including e-safety (Kanižaj et al., 2014). Furthermore, the training needs to provide further professional development for teachers in the area of e-safety in order for them to be able to prevent electronic violence and deal with children's safety on the Internet successfully (Wishart, 2004; Zogby/463, 2011; Bilić et al., 2012).

\section{DEVELOPMENT OF THE SCHOOL CURRICULUM “CHILDREN'S SAFETY ON THE INTERNET"}

In order to answer the needs for empowering students, teachers and parents in the area of e-safety, five primary schools in Croatia carried out the project called "Children's safety on the Internet" from August 2013 until December 2014. The project was developed by five primary schools that were willing to form a team and write a project proposal for grant. The schools in question were: Veliki Bukovec Primary School, together with partners at Popovača Primary School, Mladost Primary School, Gripe Primary School and Mato Lovrak Primary School . The project was financed from the grant scheme "Further development and implementation of the Croatian Qualifications Framework" (Europeaid/131254/ M/ ACT/HR). The project associates included The Education and Teacher Training Agency, the Croatian Academic and Research Network CARNet, the Croatian Personal Data Protection Agency, the Association Partners in learning, the Municipalities of Veliki and Mali Bukovec, the Brod-Posavina County, The City and University Library of Osijek, the City of Nova Gradiška and the Tourism Office of Nova Gradiška.

The project aims were:

$>$ To develop and implement the school curriculum area for children's safety on the Internet; 
$>$ To raise the students', teachers', parents' and general public's awareness and understanding of issues relating to children's safety online in synergy with the EU policies;

$>$ To develop a learning outcomes-based school curriculum area for children's safety on the Internet;

$>$ To develop and implement an accompanying pedagogical model for student-centred learning;

$>$ To improve the primary school teachers' educational skills and expertise for studentcentred approach;

> To improve students' digital competences and develop a critical attitude towards responsible use of ICT (Kralj, 2014).

The existing national curricula in Croatia (MZOS, 2006) focus mainly on the content and its delivery, without establishing learning outcomes and standards of their acquisition. There is no Information Communication Technology as an obligatory subject or as crosscurricular topics. In her comparative analysis of national curricula in European Countries and in Croatia, Branislava Baranović stated that "Croatian national curriculum is still a traditional one (subject-base prescriptive), without adequate presence of the contents and components that would enable a development of the new competencies for life in a knowledge society". (2006: 199) Such traditional curricula are at the same time completely closed systems and therefore they do not encourage schools, teachers and students' autonomy or freedom to choose the content, the methods and the way of working. On the other hand, modern, relevant and student-centred curricular solutions are based on learning outcomes which encompass the development of children and students. They are open to changes and constant innovation which go hand in hand with the development of society, economy, science, technology and education (Winter, 2012; Priestly et al., 2014).

The curriculum "Children's safety on the Internet" has been designed in a way which gives schools, teachers and students certain autonomy in choosing the content, methods and forms of work. It provides the educational and learning outcomes and standards of their acquisition whilst addressing all key competences of the European Union following violence prevention strategies and guidelines (Olweus, 1998; Lorenz et al., 2012). Also, it provides a set of standards of development and acquisition of learning outcomes which are the basis for objective assessment of achievements with various forms of internal and external assessment (Mullis et al., 2011).

The characteristics of the curriculum "Children's safety on the Internet" are:

> dedication to development of key lifelong learning competences;

$>$ focus on active learning and development, and acquiring knowledge and skills on a higher cognitive level instead of mere delivery of huge amounts of information;

$>$ focus on developmental aspects which are not exclusively cognitive (skills, attitudes, creativity, innovativeness, critical thinking, initiative, entrepreneurship, aesthetic assessment, attitude towards oneself, others, environment and such);

>clearly defined learning outcomes; 
>open didactic and methodological systems which enable teachers and students' freedom to choose content, methods and way of working;

> clearly set standards of development and acquisition of learning outcomes.

The curriculum "Children's safety on the Internet" consists of four courses and it is vertically organised in five units: information, communication, content production, safety and problem solving; according to the recommendation by the European Framework for understanding and developing digital competences in Europe (Ferrari, 2013). Each course is aimed at a certain age group of primary school children in Croatia. The first course is developed for pupils in grades 1 and 2, the second course for pupils in grades 3 and 4, the third course for pupils in grades 5 and 6 and finally, the fourth course for pupils in grades 7 and 8 . Each course is divided into 20 topics (80 topics altogether) which are to be implemented during a school year, 10 topics in each grade. The topics covered range from personal data protection, e-mail phishing and scams, netiquette, online communication and collaboration, risks on social networks, responsible use of mobile devices, sharing and authoring rights, identity theft, digital footprints, e-portfolios and online presence, evaluation of information on the Internet, to how to protect the computer and the family, prevention of cyberbullying (Kralj, 2014). Each course is described in terms of the learning outcomes, written according to the Croatian qualifications framework (Beljo Lučić et al., 2009), as well as according to corresponding knowledge, skills and competences. The learning and teaching content of each course includes theoretical knowledge, practical and technical skills and social competences needed for responsible, safe and appropriate use of the Internet. Evaluation methods, associated self-assessment, feedback mechanisms and procedures for improvement were planned for each course.

Each set of teaching/learning materials includes textbooks for students, teachers' guides and guides for parents and multimedia resources. Textbooks and e-books help students, teachers and parents to find their way through the topics; comic book characters guide them through the units and explain specific topics in a simple manner. The characters which illustrate various topics were created specifically for this curriculum. Special attention was paid to gender equality, therefore there are an equal number of male and female characters and it is easy for children to put themselves in the shoes of any of the characters. Along with the classic printed textbooks, students, teachers and their parents can use digital versions in PDF format, as well as digital e-books which contain all multimedia materials on a specific topic. Moreover, e-books provide students with a personalised learning platform. Students are allowed to choose content themselves texts, examples, presentations, posters, comics, exercises and quizzes to study, as well as the pace at which they will go through the content individually and learn. Digital materials have a specific design, the content is automatically adjusted to the device display and its resolution, which enables students with special learning needs to use them more ease.

The teachers' guides provide lesson plans that are colour-coded and represented by specific symbols just the same as the lessons in the textbook. Each lesson plan has the summary and the aims of the lesson accompanied by the learning outcomes and possible correlations with other school subjects. Lesson plans were enriched with suggestions 
for technology and resources so that every teacher can easily see which equipment and resources are needed and how to broaden their knowledge.

Guides for parents represent a new concept in the Croatian school system. Each lesson in the student's textbook has accompanying material in the guide for parents with short explanations and additional activities or accompanying materials on the internet and family activities which parents and children can do together at home. That way parents get a clear picture of what their children are being taught in each lesson and why. There are examples that clearly show which level of knowledge and skills students are going to achieve at school, as well as many guidelines on how to assist their children successfully and follow their progress in acquiring new knowledge and skills necessary for safe and acceptable use of the Internet.

Each course set includes a great number of multimedia and digital resources such as web sites, computer games, board games, interactive quizzes, cartoons and animated stories, audio and video clips which all give students an opportunity to learn individually, through games and problem-solving activities the purpose of which is for children to identify with real life characters, their peers in different situations, and a chance to explore, check and practice what they have learned. More than 800 learning resources are organised in a database for easier finding and the search tool is available on the project website Petzanet.hr.

\section{PILOTING OF THE CURRICULUM AND LEARNING RESOURCES}

The curriculum "Children's safety on the Internet" was piloted in five primary schools with 105 students, their parents and teachers. In this paper we will present and discuss findings from the piloting done in the early grades, $1-4$, with students aged 7 to 10 . The piloting was organised in September and October 2014 in all five schools involved in this project. In every class ten lessons were delivered within the weekly schedule, two lessons each week. That was intensive learning dictated by the tight project schedule. In the usual learning, as planned in the curriculum development, lessons would be delivered during a longer period, perhaps once a month according to the teacher's decision. The piloting of the curriculum was monitored by using the pre-test and post-test questionnaires created especially for this project with age-appropriate language and design accompanied with teachers' diaries and focus groups with students and parents after the curriculum was delivered.

In the pre-testing there were 25 students of the $1^{\text {st }}$ grade; 44 students of the $2^{\text {nd }} ; 18$ students of the $3^{\text {rd }}$ and 18 students of the $4^{\text {th }}$ grade. In the post-testing there were 22 students of the $1^{\text {st }}$ grade; 43 students of the $2^{\text {nd }} ; 18$ students of the $3^{\text {rd }}$ and 19 students of the $4^{\text {th }}$ grade. In the pre-test $49.5 \%$ were male and $50.5 \%$ female pupils and in the posttest $46.8 \%$ were male and $53.2 \%$ female pupils. The differences in number of students in pre- and post-testing exist due to the fact that some students were not at school on that particular day. 
The questionnaire consisted of three groups of questions: general, e-safety and digital skills, and satisfaction with learning resources. The questions about the Internet show that most students know what the Internet is, that they use it and that they started to use it very early, some of them at the age of one.

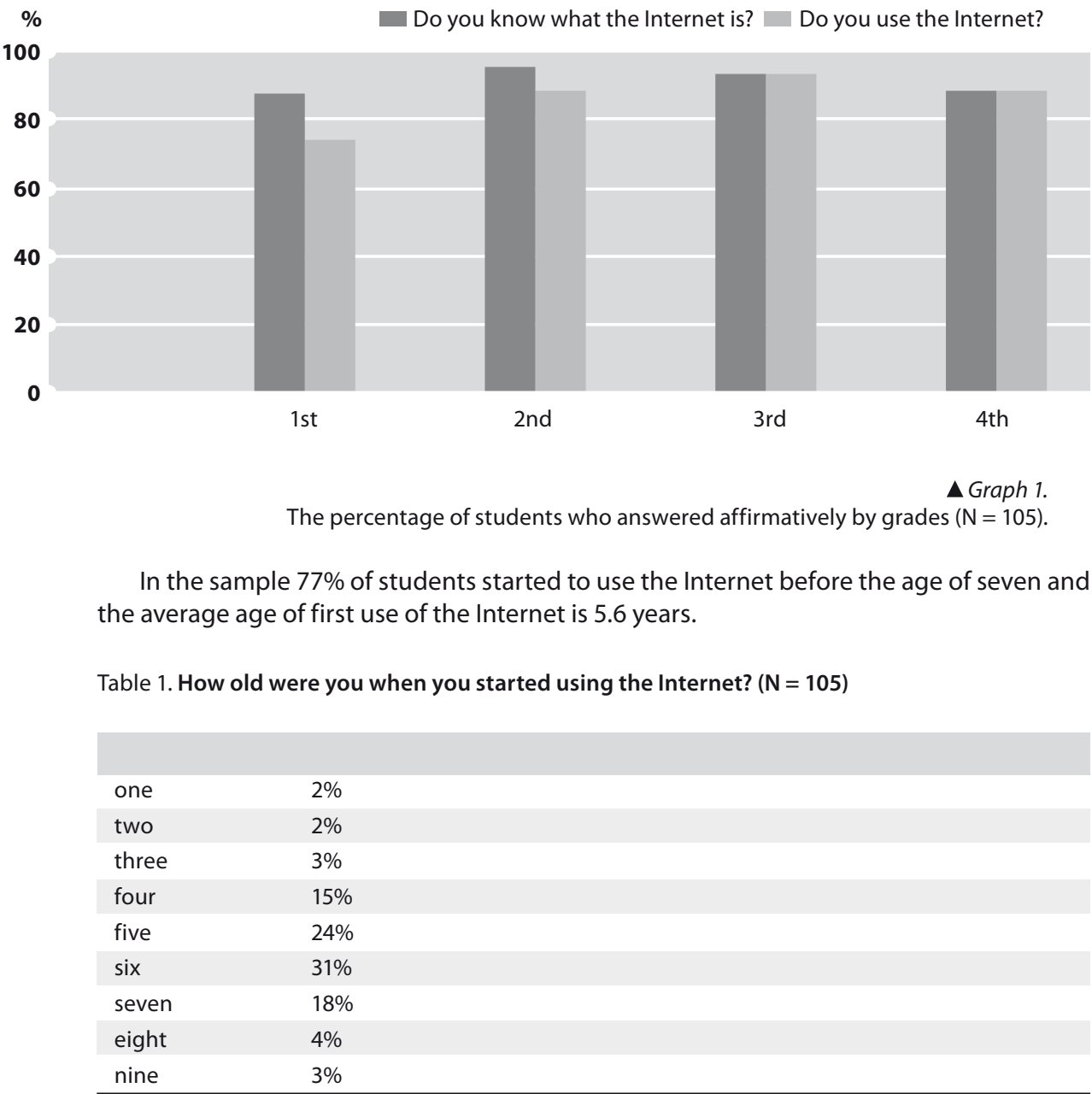

The questions regarding digital skills and cyberbullying were asked before and after the curriculum delivery. Some of them show increase in knowledge, skills and attitudes (Table 2 and Table 7) but some show that further actions are needed. Since one questionnaire is used for students in grades 1 and 2 and another one for students in grades 3 and 4,some of the results were presented together. 
Table 2. Students' reactions to threat before and after curriculum implementation.

$\begin{array}{lllll}\begin{array}{l}\text { If someone treated you in a hurtful and nasty way over the Internet or your mobile phone, } \\ \text { what would you do? (multiple answers, \%) }\end{array} & \begin{array}{l}\text { Before the curriculum } \\ \text { implementation }\end{array} & \begin{array}{l}\text { After the curriculum } \\ \text { implementation }\end{array} \\ \begin{array}{lllll} & 1^{\text {st }} \& 2^{\text {nd }} & 3^{\text {rd }} \& 4^{\text {th }} & 1^{\text {st }} \& 2^{\text {nd }} & 3^{\text {rd }} \& 4^{\text {th }} \\ \hline \text { Would not tell anyone } & 14.7 & 2.9 & 3.1 & 0 \\ \text { Inform parents } & 91.2 & 97.1 & 100 & 97 \\ \text { Inform teachers } & 48.5 & 74.3 & 89.2 & 97 \\ \text { Tell a friend } & 33.8 & 42.9 & 53.8 & 0 \\ \text { Call the police } & 27.9 & 40 & 52.3 & 78.8 \\ \text { Wouldn't answer to the threat } & 48.5 & 45.7 & 76.9 & 63.6 \\ \text { Say nasty things back } & 1.5 & 0 & 1.5 & 0 \\ \text { Erase hurtful messages } & 55.9 & 54.3 & 76.9 & 36.4 \\ \text { Block the bully so he can't contact me again } & 79.4 & 48.6 & 92.3 & 45.5 \\ \hline\end{array}\end{array}$

Pre-test $1^{\text {st }}$ and $2^{\text {nd }} \mathrm{N}=69 ; 3^{\text {rd }}$ and $4^{\text {th }} \mathrm{N}=36$. Post-test $1^{\text {st }}$ and $2^{\text {nd }} \mathrm{N}=65 ; 3^{\text {rd }}$ and $4^{\text {th }} \mathrm{N}=37$.

In the research done by UNICEF (Pregrad et al., 2011) students listed parents, friends, some adult, siblings, administrator, police and teachers as persons whom they could ask for help in case of electronic violence. In that research, some previous research (Cross et al., 2009) and in EU Kids Online 2014 (Smahel and Wright, 2014) teachers are low on the list of helpers in cases of electronic violence. We found out that after the curriculum was implemented students' recognition of teachers as helpers raised. Students' response to threats showed that a lesson about asking for help and guidance is needed in the school curriculum, which is one of the recommendations in EU Kids Online 2014: "Integrate online safety awareness and digital skills across the curriculum." (Livingstone et al., 2014: 35) The results presented in Table 2 also show that older students realised that messages could be used as evidence and that just erasing them is not useful. The percentages of students staying calm and not answering to violence with violence are increasing, which is positive.

Table 3. Sharing hurtful photos

\begin{tabular}{|c|c|c|c|c|}
\hline \multicolumn{5}{|c|}{$\begin{array}{l}\text { If you get a funny photo that offends friends from your school, would you forward it to one } \\
\text { of your friends? (\%) }\end{array}$} \\
\hline & \multicolumn{2}{|c|}{$\begin{array}{l}\text { Before the curriculum } \\
\text { implementation }\end{array}$} & \multicolumn{2}{|c|}{$\begin{array}{l}\text { After the curriculum } \\
\text { implementation }\end{array}$} \\
\hline & $1^{\text {st }} \& 2^{\text {nd }}$ & $3^{\text {rd }} \& 4^{\text {th }}$ & $1^{\text {st }} \& 2^{\text {nd }}$ & $3^{\text {rd }} \& 4^{\text {th }}$ \\
\hline Yes & 1.5 & 2.8 & 1.5 & 0 \\
\hline No & 91 & 88.9 & 98.5 & 97 \\
\hline I don't know & 7.5 & 8.3 & 0 & 3 \\
\hline
\end{tabular}

Pre-test $1^{\text {st }}$ and $2^{\text {nd }} \mathrm{N}=69 ; 3^{\text {rd }}$ and $4^{\text {th }} \mathrm{N}=36$. Post-test $1^{\text {st }}$ and $2^{\text {nd }} \mathrm{N}=65 ; 3^{\text {rd }}$ and $4^{\text {th }} \mathrm{N}=37$. 
When asked what they would do in a situation with a hurtful photo, described in the form of an animated story in the learning resources, students improved their attitude showing that almost all of them would react responsibly in a similar situation.

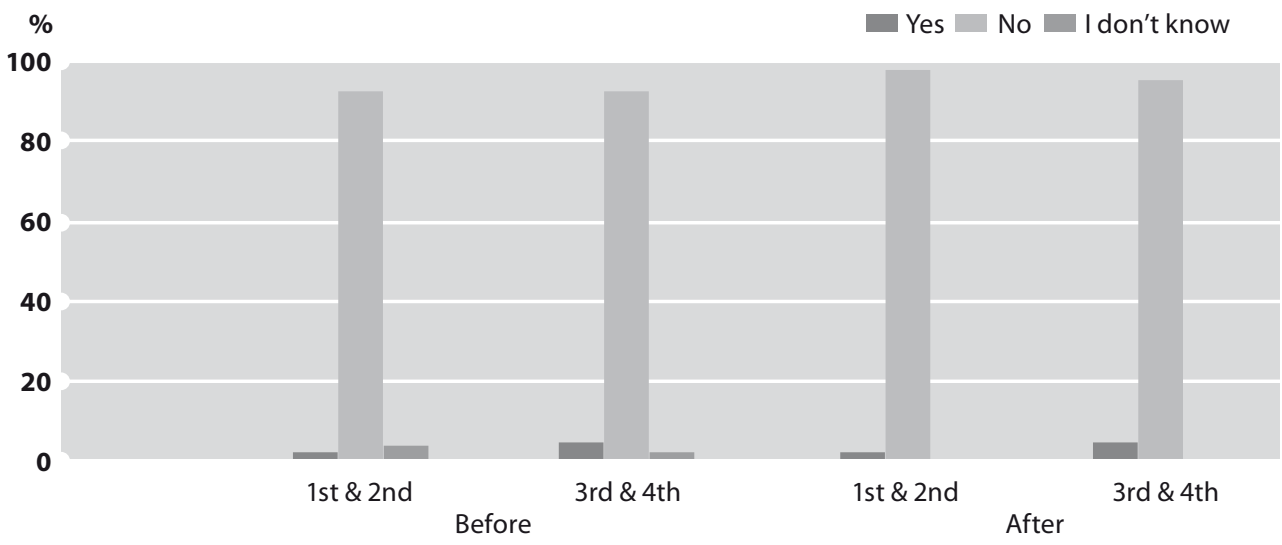

$\Delta$ Graph 2.

Is it all right to write bad things about each other on the Internet? (\%)

Almost all students were aware that writing bad things about each other on the Internet is not good behaviour so $92.6 \%$ of $1^{\text {st }}$ and $2^{\text {nd }}$ graders and $91.7 \%$ of $3^{\text {rd }}$ and $4^{\text {th }}$ graders choose not to do such a thing even before the curriculum was implemented. After the implementation of the curriculum, the percentage of younger students who believe they could not erase data or comments online rose from $31.8 \%$ to $76.9 \%$.

Table 4. Sharing personal information on the Internet

$\begin{aligned} & \text { Is it wise to share your personal information (name, address, telephone number) on the } \\
& \text { Internet? (\%) }\end{aligned}$
\begin{tabular}{llllll}
\multicolumn{4}{l}{ Before } & \multicolumn{4}{l}{ After } \\
\multicolumn{1}{l}{$1^{\text {st }} \& 2^{\text {nd }}$} & $3^{\text {rd }} \& 4^{\text {th }}$ & $1^{\text {st }} \& 2^{\text {nd }}$ & $3^{\text {rd }} \& 4^{\text {th }}$ \\
\hline Yes & 6.1 & 0 & 0 & 18.2 \\
No & 77.3 & 97.2 & 98.5 & 81.8 \\
I don't know & 16.7 & 2.8 & 1.5 & 0 \\
\hline
\end{tabular}

Pre-test $1^{\text {st }}$ and $2^{\text {nd }} \mathrm{N}=69 ; 3^{\text {rd }}$ and $4^{\text {th }} \mathrm{N}=36$. Post-test $1^{\text {st }}$ and $2^{\text {nd }} \mathrm{N}=65 ; 3^{\text {rd }}$ and $4^{\text {th }} \mathrm{N}=37$.

After the implementation of the curriculum $18.2 \%$ of the $3^{\text {rd }}$ and $4^{\text {th }}$ graders changed their minds and said it was wise to share personal information. Similar results were shown in replies to the question about online impersonation; although in the pre-test only $2.8 \%$ said it was all right to use a false name on the Internet, $6.1 \%$ agreed with that in the post- 
test. That shows that the lessons about personal information and online impersonation need more attention in implementation.

Older students answered the three questions about communication with unknown people online and meeting those people offline. The results showed that before the curriculum implementation, $22.2 \%$ of students would have communicated with a stranger online but after the implementation number lowered to $12.1 \%$. In the pre-test $25 \%$ students said they would not inform anybody if they were meeting a stranger offline, but in the post-test $6 \%$ of them would do the same. Most of students would inform parents and teachers about meeting a stranger offline (pre-test $75 \%$, post-test $94 \%$ ).

Table 5. Parents monitoring

Should parents monitor what you do on the Internet? (\%)

\begin{tabular}{llllll} 
& Before & \multicolumn{3}{c}{ After } \\
& $1^{\text {st }} \& 2^{\text {nd }}$ & $3^{\text {rd }} \& 4^{\text {th }}$ & $1^{\text {st }} \& 2^{\text {nd }}$ & $3^{\text {rd }} \& 4^{\text {th }}$ \\
\hline Yes & 89.6 & 66.7 & 87.7 & 84.8 \\
No & 6 & 33.3 & 4.6 & 15.2 \\
I don't know & 4.5 & 0 & 7.7 & 0
\end{tabular}

Pre-test $1^{\text {st }}$ and $2^{\text {nd }} \mathrm{N}=69 ; 3^{\text {rd }}$ and $4^{\text {th }} \mathrm{N}=36$. Post-test $1^{\text {st }}$ and $2^{\text {nd }} \mathrm{N}=65 ; 3^{\text {rd }}$ and $4^{\text {th }} \mathrm{N}=37$.

The question about parental involvement in children's use of the Internet showed that after learning about Internet possibilities younger students decided that parental monitoring was no longer needed or that they were not sure what parents could do. Older students showed the expected outcome but it could also be affected by students knowing what the appropriate answer would be. As the EU Kids online and UNICEF research stated, parental involvement in children's use of the Internet is important (Livingstone et al., 2011; Pregrad et al., 2011).

Table 6. Critical thinking and evaluation

\begin{tabular}{lllll} 
Can you believe everything you read on the Internet? $(\%)$ & \\
\multicolumn{7}{l}{ Before } & After \\
& $1^{\text {st }} \& 2^{\text {nd }}$ & $3^{\text {rd }} \& 4^{\text {th }}$ & $1^{\text {st }} \& 2^{\text {nd }}$ & $3^{\text {rd }} \& 4^{\text {th }}$ \\
\hline Yes & 20.9 & 0 & 4.7 & 0 \\
No & 79.1 & 100 & 87.5 & 100 \\
I don't know & 0 & 0 & 7.8 & 0 \\
\hline
\end{tabular}

Pre-test $1^{\text {st }}$ and $2^{\text {nd }} \mathrm{N}=69 ; 3^{\text {rd }}$ and $4^{\text {th }} \mathrm{N}=36$. Post-test $1^{\text {st }}$ and $2^{\text {nd }} \mathrm{N}=65 ; 3^{\text {rd }}$ and $4^{\text {th }} \mathrm{N}=37$.

Research The International Computer and Information Literacy Study (ICILS), conducted by IEA - International Association for the Evaluation of Educational Achievement, 2013 in 21 countries showed that only $1 \%$ of Croatian teenagers are on the highest level of 
computer and information literacy that includes critical evaluation (Fraillon et al., 2014). Although the results from ICILS cannot be compared with results of this question it shows that young students tend to believe everything they find on the Internet. Considering the fact that $77 \%$ of them started to use the Internet before entering $1^{\text {st }}$ grade, the importance of lessons developing critical evaluation of information in the curriculum turns out to be furtherly emphasised.

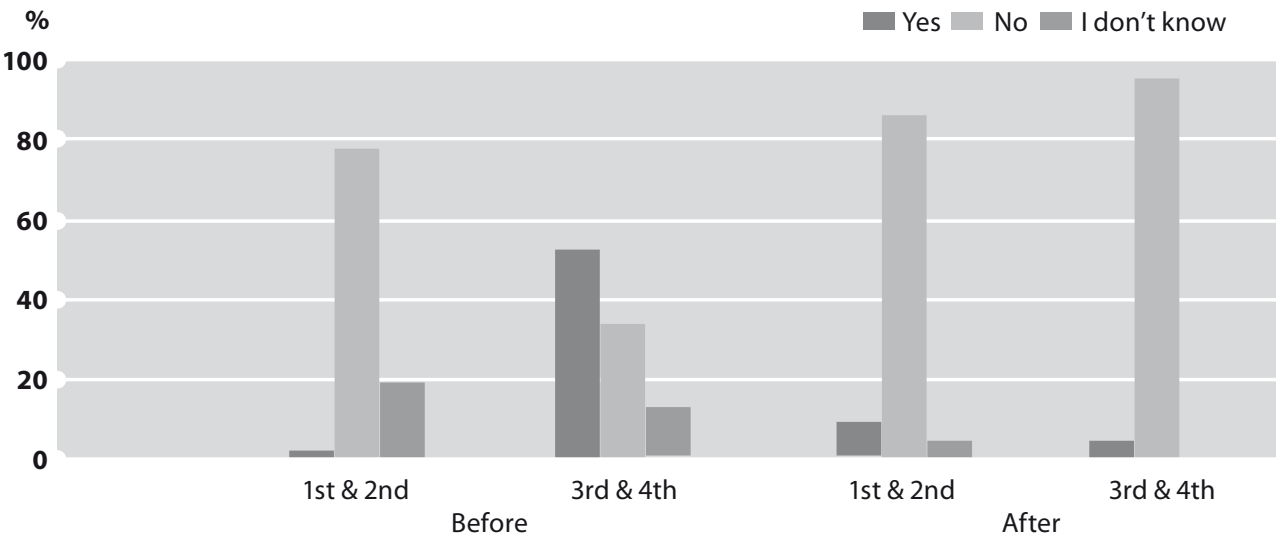

A Graph 3.

Students' answers regarding the use a photo from the Internet without permission. Pre-test $1^{\text {st }}$ and $2^{\text {nd }} \mathrm{N}=69 ; 3^{\text {rd }}$ and $4^{\text {th }} \mathrm{N}=36$. Post-test $1^{\text {st }}$ and $2^{\text {nd }} \mathrm{N}=65 ; 3^{\text {rd }}$ and $4^{\text {th }} \mathrm{N}=37$.

The questions about copyright and creative commons showed that some students are aware of the fact that everything on the Internet is not free for use but most of them need more explanation and help regarding usage and referencing. That topic was complex for the $1^{\text {st }}$ and $2^{\text {nd }}$ graders and was simplified explaining the difference between a picture they create themselves and a picture created by their peers.

Other questions which test digital skills gained showed that $3^{\text {rd }}$ and $4^{\text {th }}$ grade students digital skills were improved so now they know what search engines and videoconferences are, how to use Internet for learning, what the health and ecological risks of technology use are (Table 7).

Table 7. Change in level of some digital skills

\begin{tabular}{lll} 
3rd \& 4th grade students & Before (N=36) & After (N=37) \\
Know what videoconferences are. & $34.5 \%$ & $54.5 \%$ \\
Know that the Internet can be used for learning. & $88.9 \%$ & $100 \%$ \\
Know that throwing away your old mobile phone is not good. & $94.4 \%$ & $97 \%$ \\
Know that throwing away your old mobile phone is not good. & $88.9 \%$ & $97 \%$ \\
Know that Google is an Internet search engine. & $50 \%$ & $97 \%$ \\
\hline
\end{tabular}


The final part of the evaluation questionnaire contained questions regarding students' satisfaction with learning resources. Younger students answered those questions with only Yes-No options (because they are not familiar with grading with numbered marks) and older ones gave marks from 1 to 5 . The overall rating was $94 \%$ Yes from younger students, and an average mark of 4.8 from older students. Such high grades show that students were fully satisfied with learning resources and that the team of authors successfully implemented modern strategies (exploration, dialogue, simulation, gamification, project and problem based learning) in the curriculum and resources creation. Comparing students' satisfaction with different kinds of learning resources, younger students liked animated stories and videos the most (94\%), than games and worksheets (93.8\%), e-books (83\%) and in the last place textbooks (80\%). Older students had almost the same ranking: games (average mark 4.9), animated stories and videos (4.8), than textbooks and e-books (4.78) and in the last place worksheets (4.75).

When asked the question "Would you like to have lessons about children's safety on the Internet next year too?" 97\% of students from all grades answered affirmatively, which is also a sign that the curriculum content, learning resources and the way of teaching was set up in the way that suits the needs of today's learners.

The answers regarding competences of friends who did not take part in this research are interesting. That question also addresses one of the important digital competences helping others, sharing knowledge and bridging the digital gap (Hsiao et al., 2014).

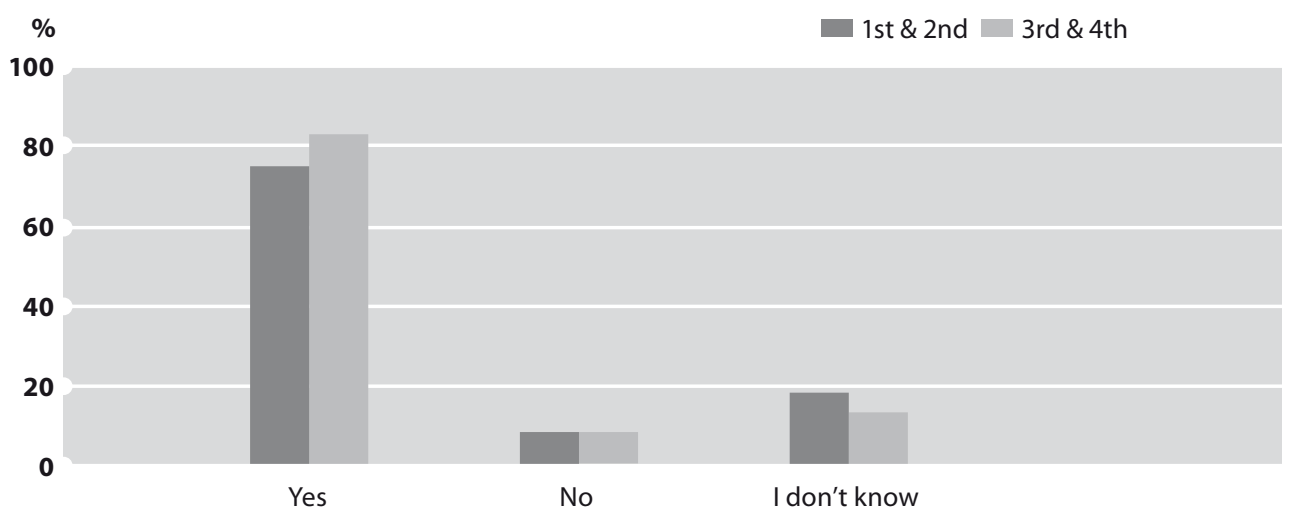

A Graph 4.

Do you think that your friends need additional knowledge about the use of the Internet, its good and bad sides? (\%) $1^{\text {st }}$ and $2^{\text {nd }} \mathrm{N}=65.3^{\text {rd }}$ and $4^{\text {th }} \mathrm{N}=37$ 
80 parents of the children who took part in this project in five primary schools participated in the focus groups for parents. The focus groups were organised at the end of the project in each participating school as a tool to get feedback from parents and the same questions were asked in every group no matter how old their children were. Parents said they frequently used internet, most of them every day and that they paid attention to what their children did online. According to parents they watch cartoons usually together, play games or listen to music online together. Parents said that their children started to use internet at the age of three or four, which is consistent with the students' answers in Table 1. Parents stated that before the project "Children's safety on the Internet" they did not talk about the Internet with children too much, but rather about the usage of mobile phones. They admitted that children often discover possibilities of computer and mobile devices by themselves but $30 \%$ of parents were moderating and teaching their children about harmful content on the Internet.

Although all students in this research were younger than 13, which is the legal limit for the use of social networks, parents of younger students mentioned that students used Facebook,some of them using nicknames, some of them using their real names. Only a few parents have passwords to their children's profiles on Facebook, some follow children's activities online as their Facebook friends, but some have no idea what their children do on Facebook.

The guides for parents accompany each lesson from the student's textbook with short explanations, additional family activities which parents and children can do together at home. The aim of these guides was to give parents more information of what their children are being taught in each lesson and why. The guide for parents was not used much, some parents read some parts, some checked it out on the project webpage but so far only a few parents read them completely. A possible reason could be that the guide for parents was not available in a printed form during the piloting of the curriculum. The research has also showed that if an elective subject about e-safety was offered, all parents would enrol their children, but they suggested that teaching about e-safety would be more efficient if taught as part of all regular subjects in primary school and not as a separate subject. The results from Jocelyn Wishart's 2004 research in UK schools showed that e-safety teaching is most likely to take place in the subject area of ICT but the percentage of UK teachers not teaching e-safety remains as high as 42\% (Sharples et al., 2009).

Most of parents are willing to attend lectures and workshops about e-safety but $30 \%$ think they know enough and that such a thing is not needed for them.

15 teachers delivered the curriculum at five primary schools and wrote their comments in an implementation diary. The implementation diary was used to gather feedback about pedagogical aspects and to collect teachers' advice for resources improvement. The teachers emphasised that students were very motivated for the activities prescribed by the curriculum, they said that children took an active part and used the interactive resources on tablets easily. As far as learning resources are concerned, the teachers said 
they were well adjusted to the students' age and that they contained all information needed and in a format that was interesting to students.

The teachers were satisfied with the learning resources and all additional resources that were available for teaching each specific lesson. They marked the learning resources with the 4.8 out of 5 mark. One of the results of this project is that the curriculum material for $1^{\text {st }}$ graders was not adopted to be used at the beginning of school year (we tested it in this period because of project time limitations). The $1^{\text {st }}$ grade teachers from the $1^{\text {st }}$ grade stressed that most of the students did not know how to read and write, which caused some difficulties for them at the beginning, so they suggested that lessons planned for the 1st grade should be delivered in the second semester of the school year.

The piloting also gave teachers the opportunity to make small changes, adjusting some activities to the abilities of their students, like using verbal answering rather than in writing, or showing examples in front of the whole class instead of working in groups. Lessons were mostly delivered during the so-called 'classmaster's class', Croatian language, Science and English language classes.

\section{CONCLUSION}

The limitations of this research were a strict timeframe of project implementation, and a small number of students, teachers, parents and schools. The project timeframe dictated a narrow time slot for the implementation of the curriculum and its piloting, so we found out that the implementation was more intense than originally planned. Because of having such a short period of time, it was possible to carry out the piloting of the curriculum only in a small number of classes and with the available resources. For this reason, we see this research as a pre-test for a more representative long-term research. However, the research outcomes allowed us to improve the quality of the curriculum and of the learning resources and, after that, all updated resources were published online, for unlimited use.

What is promising is that in $2014 / 15$ school year alongside with the originally planned five schools, around 20 schools started to use the learning resources and in the 2015/16 school year the number of schools rose to over 50. Also, the learning resources and the school curriculum "Children's safety on the Internet" under its short name "Pet za net" continued implementation in primary schools of the Sisak-Moslavina County and have found their place in the new national curriculum for the cross-curricular subject called Use of ICT as well as in the curriculum for the school subject of Informatics (Computer Science) in all primary and secondary schools in Croatia. 


\section{References}

>Baranović, Branislava (2006) Nacionalni kurikulum u europskim zemljama i Hrvatskoj: komparativan prikaz. Sociologija i prostor 44 (172/173 2/3): 181-200.

$>$ Beljo Lučić, Ružica, Buntić Rogić, Alenka, Dubravac Šigir, Mihaela, Dželalija, Mile, Hitrec, Suzana, Kovačević, Sonja, Krešo, Marinela, Lekić, Mirela, Mrnjaus, Kornelija, Rašan Križanac, Marija, Štajduhar, Mirna and Tatalović, Marina (2009) Hrvatski kvalifikacijski okvir, Uvod u kvalifikacije. Zagreb: Vlada Republike Hrvatske, Ministarstvo znanosti obrazovanja i sporta.

>Bilić, Vesna, Buljan Flander, Gordana and Hrpka, Hana (2012) Nasilje nad djecom i među djecom. Jastrebarsko: Naklada Slap.

>Buljan Flander, Gordana (2013) Istraživanje o iskustvima i ponašanjima djece na Internetu i na društvenoj mreži Facebook. http://www.poliklinika-djeca.hr/istrazivanja/istrazivanje-o-iskustvima-iponasanjima-djece-na-internetu-i-na-drustvenoj-mrezi-facebook-2/ (15.07.2016).

$>$ Cross, Emma-Jane, Richarson, Ben, Douglas, Thaddaeus and Vonkaenel-Flatt, Jessica (2009) Virtual Violence: Protecting Children from Cyberbullying. London: Beatbullying.

>European Parliament and the Council (2006) Key Competencies for Lifelong Learning, European Reference Framework. Luxembourg: Office for Official Publications of the European Communities. http://eur-lex.europa.eu/legal-content/HR/TXT/?uri=uriserv:c11090 (01.07.2016).

>Ferrari, Anja (2013) DIGCOMP: A Framework for Developing and Understanding Digital Competence in Europe. Luxembourg: Publications Office of the European Union.

>Fraillon, Julian, Ainley, John, Schulz, Wolftam, Friedman, Tim and Gebhardt, Eveline (2014) Preparing for Life in a Digital Age: The IEA International Computer and Information Literacy Study international report. Melbourne: IEA \& Springer Open. DOI: 10.1007/978-3-319-14222-7.

$>$ Hsiao, Hsien-Sheng, Chang, Cheng-Sian, Lin, Chien-Yu, Chang, Chih-Chun and Chen, Jyun-Chen (2014) The Influence of Collaborative Learning Games within Different Devices on Student's Learning Performance and Behaviours. Australasian Journal of Educational Technology 30 (6): 652-669.

>Kanižaj, Igor, Car, Viktorija and Kralj, Lidija (2014) Media and Information Literacy Policies in Croatia (2013). Paris: ANR TRANSLIT and COST "Transforming Audiences/Transforming Societies". http:// ppemi.ens-cachan.fr/data/media/colloque140528/rapports/CROATIA_2014.pdf (10.07.2016). $>$ Kralj, Lidija (2014) Children's Safety on the Internet - Development of the School Curriculum. Information and Communication Technology, Electronics and Microelectronics (MIPRO) 37: 593-596. DOI: 10.1109/MIPRO.2014.6859637.

>Livingstone, Sonia, Haddon, Leslie, Görzig, Anke and Ólafsson, Kjartan (2011) Risks and Safety on the Internet: The perspective of European children, Full Findings. London: EU Kids Online, LSE. >Livingstone, Sonia, Mascheroni, Giovanna, Ólafsson, Kjartan and Haddon, Leslie (2014) Children's Online Risks and Opportunities: Comparative Findings from EU Kids Online and Net Children Go Mobile. London: EU Kids Online, LSE.

>Lorenz, Birgy, Kikkas, Kaido and Laanpere, Mart (2012) Comparing Children's E-Safety Strategies with Guidelines Offered by Adults. Electronic Journal of e-Learning 10 (3): 326-338.

$>$ Mark, Lauren and Ratliffe, T. Katherine (2011) Cyber worlds: New Playgrounds for Bullying. Computers in the Schools 28: 92-116. DOI: 10.1080/07380569.2011.575753.

$>$ Ministry of Science, Education and Sport (2006) Nastavni plan i program za osnovnu školu, (Teaching Plan and Program for Primary School. http://mzos.hr (01.07.2016). >Mullis, Ina V.S., Martin, Michael O., Minnich, Chad A., Drucker, Kathleen T., Ragan, Moira A. (eds) (2011) PIRLS 2011 Encyclopaedia: Education Policy and Curriculum in Reading. Volume 1: A-K. Chestnut Hill: International Association for the Evaluation of Educational Achievement.

>Olweus, Dan (1998) Nasilje među djecom u školi: Što znamo i što možemo učiniti? (Bullying at school: What we know and what we can do?). Zagreb: Školska knjiga.

$>$ Pregrad, Jasenka, Tomić Latinac, Martina, Mikuluć, Marija and Šeparović, Nikolina (2011) Iskustva i stavovi djece, roditelja i učitelja prema elektroničkim medijima (Experiences and attitudes of children, parents and teachers toward electronic media). Zagreb: Ured UNICEF-a za Hrvatsku. 
$>$ Priestley, Mark, Minty, Sarah and Eager, Michelle (2014) School-Based Curriculum Development in Scotland: Curriculum Policy and Enactment. Pedagogy, Culture and Society 22 (2): 189-211. DOI: 10.1080/14681366.2013.812137.

>Sharples, Mike, Graber, Rebecca, Harrison, Colin and Logan, Kit (2009) E-safety and Web 2.0 for Children aged 11-16. Journal of Computer Assisted Learning 25 (1): 70-84.

$>$ Smahel, David and Wright, Michelle F. (2014) The Meaning of Online Problematic Situations for Children: Results of Qualitative Cross-cultural Investigation in Nine European Countries. EU Kids Online. London: London School of Economics and Political Science.

$>$ Winter, Christine (2012) School Curriculum, Globalisation and the Constitution of Policy Problems and Solutions. Journal of Education Policy 27 (3): 295-314. DOI: 10.1080/02680939.2011.609911.

$>$ Wishart, Jocelyn (2004) Internet Safety in Emerging Educational Contexts. Computers \& Education 43 (1-2): 193-204. DOI: 10.1016/j.compedu.2003.12.013.

>Zogby/463 (2011) The State of K-12 Cyberethics, Cybersafety and Cybersecurity Curriculum in the United States National Cyber Security Alliance. http://www.staysafeonline.org/download/ datasets/2052/2011_national_k12_study.pdf (01.01.2016). 


\section{E-SIGURNOST I DIGITALNE VJEŠTINE KAO DIO ŠKOLSKOG KURIKULA}

\section{Lidija Kralj}

SAŽETAK Kako bi se odgovorilo na potrebe osnaživanja učenika, učitelja i roditelja u području e-sigurnosti, prevencije elektroničkog nasilja i digitalnih vještina, pet osnovnih škola u Republici Hrvatskoj provelo je projekt "Sigurnost djece na internetu". U ovom radu razmatramo sadržaj i vrednovanje školskog kurikula "Sigurnost djece na internetu" razvijenog u tom projektu te rezultate njegova pilottestiranja na nižim razredima osnovne škole, s učenicima starosti od 7 do 10 godina, njihovim roditeljima i učiteljima. Rezultati pokazuju da je kurikul ispunio očekivanja učenika te da je autorski tim uspješno primijenio suvremene nastavne strategije u kurikulu i pri stvaranju obrazovnih sadržaja (udžbenika, priručnika, interaktivne multimedije, e-knjiga), iako su neki rezultati pokazali da neke nastavne lekcije treba pojasniti kako bi se ostvarili očekivani ishodi učenja. Rezultati pilot-testiranja odmah su se koristili za poboljšanje kvalitete kurikula te su nakon toga svi sadržaji za učenje i poučavanje objavljeni online $i$ besplatno su dostupni. Obrazovni sadržaji našli su svoje mjesto u prijedlogu novog nacionalnog kurikula za međupredmetnu temu „Uporaba informacijske i komunikacijske tehnologije (IKT)", kao i u kurikulu predmeta Informatika za sve osnovne i srednje škole u Republici Hrvatskoj.

\section{KLJUČNE RIJEČI}

E-SIGURNOST, PREVENCIJA ELEKTRONIČKOG NASILJA, ŠKOLSKI KURIKUL, DIGITALNE VJEŠTINE

Bilješka o autorici

Lidija Kralj :: Visoko učilište Algebra, Zagreb :: lidija.kralj@ucitelji.hr 